\title{
Fusarium oxysporum f. sp. phaseoli and Meloidogyne incognita interaction in common bean
}

\author{
Flávia Fernandes Carneiro ${ }^{1 *}$, Magno Antonio Patto Ramalho ${ }^{1}$, and Mônica Juliani Zavaglia Pereira ${ }^{2}$ \\ Received 2 November 2009 \\ Accepted 14 January 2010
}

\begin{abstract}
To verify a possible relationship between resistance to nematodes and to Fusarium oxysporum (Fop) in common bean, 18 lines (eight resistant and eight susceptible to Fop plus two controls) were evaluated for resistance to the nematode Meloidogyne incognita. This evaluation was conducted in a greenhouse in a randomized block design with five replications. The plot consisted of one pot with two bean plants and a nematode-susceptible tomato plant. Two weeks after sowing, plants were infested in the rhizosphere with 5000 eggs of Meloidogyne incognita, race 3. The number of egg masses was assessed, about 45 days after inoculation. Only lines ESAL 522, ESAL 519 and 'Aporé' were resistant to the nematode. Only 'Aporé' was resistant to both pathogens. The correlation between grades of Fop severity and mean egg mass was practically zero $(r=0.0252, P \leq 0.9293)$.
\end{abstract}

Key words: Pathogen resistance, Phaseolus vulgaris, interaction between pathogens.

\section{INTRODUCTION}

One of the most significant biotic stresses to bean crops is caused by nematodes, especially the genus Meloidogyne. Its occurrence is widespread and the damage is particularly striking in the case of continuous cultivation, as it occurs in center pivot-irrigated areas (Silva et al. 2003). It is mainly controlled by the use of resistant cultivars associated with management and crop practices. The identification of resistant lines has been frequently reported in the literature (Moura and Moura 1994, Pedrosa et al. 2000, Silva et al. 2005).

Another biotic stress common bean is exposed to is Fusarium oxysporium $\mathrm{f}$ sp. phaseoli (Fop). This pathogen causes wilting and early death of the plants and causes extensive damage. In this case also, the main possibility of control is the use of resistant cultivars. Several reports of resistance sources are cited in the literature (Sala et al. 2006, Pereira et al. 2008).

There is evidence, although not properly documented, that plants susceptible to nematodes are susceptible to Fop as well. It was reported that a Fusarium-resistant line can become susceptible in the presence of nematodes (France and Abawi 1994). Commonly, $M$. incognita interacts with Fop and causes a complex disease that damages the plant more intensely than the two pathogens separately (Jeefers and Roberts 2003). Therefore, the attempt to incorporate resistance to the fungus alone was little successful in soil infested with $M$. incognita. Although this interaction between the two pathogens is discussed with some frequency, no information was found on lines that are resistant to Fop as well as nematodes, which is the main goal of this study.

\footnotetext{
${ }^{1}$ Universidade Federal de Lavras (UFLA), Departamento de Biologia, C.P. 3037, 37.200-000, Lavras, MG, Brazil. *E-mail: bioffc@yahoo.com.br.

${ }^{2}$ Empresa Brasileira de Pesquisa Agropecuária, Centro Nacional de Pesquisa de Soja, Campo Experimental de Balsas, Rua da Cohab, 813, Cohab, C.P. 131, 16.5800-000, Balsas, MA, Brazil.
} 


\section{MATERIAL AND METHODS}

In a previous study, Pereira et al. (2008) had examined lines of bean germplasm bank of the Universidade Federal de Lavras (UFLA) and classified them for Fop resistance. In this study we used the method of root immersion in spore suspension, by cutting the root system, at an inoculum concentration of $10^{6}$ conidia $\mathrm{mL}^{-1}$. Evaluations were performed 21 days after inoculation (DAI), stage V3V4. Severity was graded on a scale ranging from 1 (no leaf or vascular symptoms) to 9 (susceptible). Lines with a mean score of 1.0-3.0 were considered resistant, 3.1-6.0 intermediate and 6.1-9.0 susceptible (Elena and Papas 2002).

Based on this classification, the eight most Fopresistant and eight most Fop-susceptible lines were identified. These lines, along with the two controls 'Aporé' (nematode-resistant) and 'Batatinha' (nematode-susceptible) were assessed for reaction to the nematode $M$. incognita race 3 in a randomized complete block design with five replications. Each plot consisted of a plastic pot with two bean plants. Additionally, a tomato plant was grown, cultivar 'Santa Clara', nematode-susceptible, to evaluate the pathogen occurrence. The data of tomato were used as a covariate in the analysis of variance. The experiment was conducted in a greenhouse, minimum $22^{\circ} \mathrm{C}$ to maximum $36^{\circ} \mathrm{C}$, at the Federal University of Lavras.

The $M$. incognita race 3 inoculum was obtained by multiplication on tomato plants (Lycopersicon esculentum L.) cv. 'Santa Clara', from which the eggs were extracted. For this purpose, the tomato roots were washed under running water, cut into several segments, and mixed in a blender with a solution of $0.5 \%$ sodium hypochlorite for $1 \mathrm{~min}$. The resulting suspension was sieved twice (mesh 200 and 500), the eggs collected in the second sieve, and later counted out on the suspension with a magnifying glass, according to the methodology of Boneti and Ferraz (1981). Fifteen days after sowing, the rhizosphere was infested, and approximately 5000 eggs per plant were inoculated.

The plant response to the parasitic nematode was evaluated by counting the number of egg masses, about 45 days after inoculation, at the R6 stage. For standardization, the number of egg masses was estimated per $10 \mathrm{~g}$ of roots. Subsequently, the roots were immersed in phloxine B dye (15 mg liter water ${ }^{-1}$ ) for $15-20 \mathrm{~min}$, to stain the egg masses.

\section{RESULTS AND DISCUSSION}

The mean values of number of egg masses per plot were subjected to analysis of covariance after transformation to square roots, using the square root of the number of egg masses on tomato as covariate (Ramalho et al. 2005).

It was found that the adjustment by the covariate was very small, indicating, in this experiment, that the use of tomato as indicator plant for nematode occurrence was not effective. However, the usefulness of this covariate was reported elsewhere (Silva et al. 2005). It should be mentioned that, with exception of the effect of replications, the source of variation of treatments explained $54.65 \%$ of the total variation, indicating that most of the variation was due to the treatments, indicating good accuracy.

The mean number of egg masses ranged from 6.1 (line ESAL 522) to 94.09 (line ESAL 525) (Table 1). Based on the test of Scott-Knott (1974) the treatments were grouped into three classes. The ones considered resistant were ESAL 522, ESAL 519 and 'Aporé'. The performance of the latter as one of the most resistant cultivars to $M$. incognita available is confirmed (Silva et al. 2005). The selection of lines with Cultivar Aporé resulted in 'Perola, one of the most planted in Brazil in recent years, particularly under central pivot irrigation. Probably, the nematode resistance of this cultivar is one of the reasons for its success (Pereira et al. 2002). The most susceptible group included 10 lines, including 'Batatinha', used as susceptibility standard, confirming its reaction to the nematode once again (Silva et al. 2005).

The main interest of this study was to verify the existence of an association between the resistance to the nematode and to Fop, as suggested by Jeffers and Roberts (2003) and France and Abawi (1994). According to Pereira et al. (2008), however, those considered resistant to Fop were highly nematode-susceptible. Only cultivar Aporé was resistant to both pathogens. On the other hand, the most nematode-resistant line, ESAL 522, was Fopsusceptible. The same was true for ESAL 519. The estimated correlation between the mean score of Fop severity and mean number of nematode egg masses confirmed these observations, as it was practically zero $(r=0.0252$, $\mathrm{P} \leq$ 0.9293). It may therefore be concluded that resistance and/or susceptibility to the two pathogens are not correlated in the lines evaluated in this study.

The discrepancy between the observations of Jeffers and Roberts (2003) and France and Abawi (1994) can be attributed to several factors. The first is the race of the 
Table 1. Reaction to Fusarium oxysporium f sp. phaseoli, assessed by Pereira et al. (2008), and mean mass of Meloidogyne incognita eggs per plant, in common bean lines

\begin{tabular}{lcc}
\hline Lines & $\begin{array}{c}\text { F oxysporum f. sp. } \\
\text { phaseoli }^{1}\end{array}$ & Nematoid $^{2}$ \\
\hline Esal 522 & 9 & $6.12 \mathrm{a}$ \\
Esal 639 & 9 & $47.98 \mathrm{c}$ \\
Esal 516 & 9 & $18.36 \mathrm{~b}$ \\
Esal 519 & 9 & $10.92 \mathrm{a}$ \\
Esal 565 & 9 & $31.43 \mathrm{~b}$ \\
Esal 525 & 9 & $94.09 \mathrm{c}$ \\
Porrilho Sintético & 9 & $46.24 \mathrm{c}$ \\
CNF 252 & 9 & $56.05 \mathrm{c}$ \\
Esal 566 & 1 & $35.45 \mathrm{~b}$ \\
CNF 243 & 1 & $31.57 \mathrm{~b}$ \\
Baetao & 1 & $26.37 \mathrm{~b}$ \\
H-87 & 1 & $44.05 \mathrm{c}$ \\
Esal 644 & 1 & $53.07 \mathrm{c}$ \\
Esal 609 & 1 & $42.86 \mathrm{c}$ \\
Esal 533 & 1 & $65.01 \mathrm{c}$ \\
Esal 550 & 1 & $76.72 \mathrm{c}$ \\
Aporé & 2.6 & $14.95 \mathrm{a}$ \\
Batatinha & 1 & $60.47 \mathrm{c}$ \\
\hline CV (\%) & & 31.19 \\
\hline
\end{tabular}

${ }^{1}$ Severity scores of Fusarium oxysporium f.sp. phaseoli (1 - healthy plants, 9 - dead plants), ${ }^{2}$ lines identified with the same letter belong to the same group by the Scott-Knott test (1974), at 5\% probability.

two agents used. There is evidence in the literature of the existence of different pathogenic races of Fusarium oxysporum f. sp. phaseoli (Alves-Santos et al. 2002). In Brazil, there are reports pointing to the existence of more than one race (Ito et al. 1997), although there are several other studies that discuss the occurrence of only one race, called Race 2 or Brazilian race (Ribeiro and Hagedorn 1979, Nascimento et al. 1995, Alves-Santo et al. 2002). In this study, the isolate was obtained in the region, probably representing the prevailing race of the country. The same is true for the nematode, of which race 3 was used in this study. Most likely, the authors mentioned above had used other races. Another explanation for the differences in results could lie in the evaluation methodology. Some argue that the nematode causes injuries to plant roots and even a Fop-resistant line may become susceptible because the resistance is related to pathogen penetration (Hillocks and Marley 1995). However, in the procedure used by Pereira et al. (2008) to assess Fop, the roots were cut before immersion in the spore suspension of the fungus. In this case, the damage caused by the nematode injury would be irrelevant in terms of the expression of Fop-resistance. A third difference is the plant age at evaluation. The plants considered Fop-resistant in this study were evaluated very young, by inoculation 9-10 days after sowing (first pair of fully expanded unifoliolate leaves) and evaluation 21 DAI, stage V3-V4.

\section{ACKNOWLEDGEMENTS}

We thank Conselho Nacional de Pesquisa e Desenvolvimento (CNPq).

\section{Interação entre Fusarium oxysporium f. sp. e Meloidogyne incognita em feijoeiro-comum}

RESUMO - Com objetivo de verificar se há associação entre a resistência ao nematóide e ao Fusarium oxysporum (Fop), dezoito linhagens de feijão, sendo oito resistentes e oito suscetíveis ao Fop mais duas testemunhas foram avaliadas com relação à reação ao nematóide Meloidogyne incognita. Essa avaliação foi realizada em casa de vegetação no delineamento de blocos casualizados com cinco repetições. A parcela foi constituída por um vaso com duas plantas de feijão, e uma de tomate suscetível ao nematóide. Aos 15 dias após a semeadura, foi realizada a infestação, na região da rizosfera, com 5000 ovos de Meloidogyne incognita, raça 3. Foi avaliado o número de massas de ovos, aproximadamente 45 dias após a inoculação. Somente as linhagens ESAL 522, ESAL 519 e 'Aporé' foram resistentes ao nematóide. Apenas a 'Aporé' foi resistente aos dois patógenos. A correlação entre as notas de severidade do Fop e o número médio de massa de ovos obtida foi praticamente nula $(r=0,0252 ; \leq 0,9293)$.

Palavras-chave: Resistência a patógenos, Phaseolus vulgaris, interação entre patógenos. 
FF Carneiro et al.

\section{REFERENCES}

Alves-Santos FM, Cordeiro-Rodrigues L, Sayagués JM, MartínDominguez R, García-Benavides P, Díaz-Mínguez JM and Eslava AP (2002) Pathogenicity and race characterization of Fusarium oxysporum f.sp. phaseoli isolates from Spain and Greece. Plant Pathology 51: 605-611.

Bonneti JIS and Ferraz S (1981) Modificação do método de Hussey \& Barker para extração de ovos de Meloidogyne exígua em raízes de cafeeiro. Fitopatologia Brasileira 6: 533.

Elena K and Papas A C (2002) Pathogenicity and vegetative compatibility of Fusarium oxysporum f.sp. phaseoli in Greece. Journal of Phytopathology 150: 495-499.

France RA and Abawi GS (1994) Interaction between Meloidogyne incognita and Fusarium oxysporum f. sp. Phaseoli on selected bean genotypes. Journal of Nematology 26: 467-474.

Hillocks RR and Marley PS (1995) Systemic effects of root-knot nematodes on mechanisms of resistance to Fusarium wilt diseases. Aspects of Applied Biology 42: 267-275.

Ito MF, Carbonell SAM, Pompeu AS, Ravagnani RC, Lot RC and Rodrigues LCN (1997) Variabilidade de Fusarium oxysporum f.sp. phaseoli. Fitopatologia Brasileira 22: 270-271.

Jeffers DP and PA Roberts (2003) Effect of plant date and host genotype on the root-knot-Fusarium wilt disease complex in cotton. Phytopathology 83: 645-654.

Moura AM and Moura RR (1994) Comportamento de genótipos de Phaseolus vulgaris em relação aos nematóide Meloidogyne incognita Raça 1 e $M$. javanica. Nematologia Brasileira 18: 50-54.

Nascimento SRC, Kurozawa C and Maringoni AC (1995) Avaliação de raças fisiológicas de Fusarium oxysporum f.sp. phaseoli. Fitopatologia Brasileira 2: 214-217.
Pedrosa EMR, Moura RM and Silva EG (2000) Resposta de genótipos de Phaseolus vulgaris à meloidoginoses e alguns mecanismos envolvidos na reação. Fitopatologia Brasileira 25: 190-196.

Pereira MJZ, Ramalho MAP and Abreu AFB (2008) Estratégias para eficiência da seleção de feijoeiro quanto à resistência à murcha-de-fusário. Pesquisa agropecuária brasileira 43: 721-728.

Pereira JM, Vieira RF and Marrara LO (2002) Reação de cultivares e linhagens de feijão à murcha-de-fusarium. Revista Ceres 49: 71-74.

Ramalho MAP, Perreira DF and Oliveira AC (2005) Experimentação em genética e melhoramento de plantas. 2nd ed., UFLA, Lavras, 326p.

Ribeiro RLD and Hagedorn DJ (1979) Screening for resistance to and pathogenic specialization of Fusarium oxysporum f.sp. phaseoli, the causal agent of bean yellows. Phytopathology 69: $272-276$.

Sala GM, Ito MF and Carbonell SAM (2006) Reação de genótipos de feijoeiro comum a quatro raças de Fusarium oxysporum f.sp. phaseoli. Summa Phytopathologica 32: 286-287.

Scott A and Knott M (1974) Cluster-analysis method for grouping means in analysis of variance. Biometrics 30: 507-512.

Silva JFV, Dias AGWP, Asmus GL and Carneiro GES (2003) Manejo integrado de nematóide na cultura da soja. Fitopatologia Brasileira 28: 31-33.

Silva FB, Ramalho MAP and Abreu AFB (2005) Genetic control of Meloidogyne incognita resistance in common bean. Annual Report of the Bean Improvement Cooperative 48: 64-65. 